\title{
THERMAL NUMERICAL INVESTIGATION OF A SMALL PARABOLIC TROUGH COLLECTOR UNDER DESERT CLIMATIC CONDITIONS
}

\author{
Mokhtar Ghodbane ${ }^{1,{ }^{*}}$, Boussad Boumeddane ${ }^{1}$, Ahmed Kadhim Hussein ${ }^{2}$, Hafiz Muhammad Ali ${ }^{3}$ \\ Dong $\mathrm{Li}^{4}$
}

\begin{abstract}
The main objective of this study is to conduct a controlled thermal investigation of a small Parabolic Trough Concentrator (PTC) under real climatic conditions for El-Oued region on 16/03/2018, where the water was adopted as a heat transfer fluid. One-dimensional and transient energy balance equations have been analyzed, simplified and then programmed with the Matlab code. What distinguishes this study is the precise tracking of all heat coefficients that would give an accurate representation of the thermal behavior of the studied device. The average optical efficiency of the device has reached $78.55 \%$, the average value of the thermal efficiency has reached $74.30 \%$, while the average value of the overall coefficient of the thermal loss is $5.96 \mathrm{~W} / \mathrm{m}^{2 \circ} \mathrm{C}$. Water steam has been formed under the effect of practical conditions between 10:20 and 11:50. The results obtained in this study encouraged the research team to start manufacturing this device with the dimensions mentioned in this paper, in order to direct this prototype setup to conduct scientific experiments will be in the field of solar cooling, desalination, water heating and other areas that serve the society welfare and maintain the environment integrity.
\end{abstract}

Keywords: Parabolic trough solar collector, Thermal solar, Thermal investigation, Pure water, Numerical simulation

\section{INTRODUCTION}

Solar energy is the heat and light coming from the sun, which human has used in his service since ancient times by using the technology traditional means that has developed to facilitate the life [1-3]. Now, solar energy has a bright future, where its uses have been widely used in many industrial and domestic fields. It can be used to heat swimming pools [4], air heating [5-7], water heating [8-12], nanofluids applications [13-16] and solar irrigation [17, 18]. In addition, it can be used to cook food in solar furnaces [19,20], where these furnaces collect sunlight at a central point and then turn sunlight into a heat. Moreover, it is used also for desalination [21, 22], drying [23-25], electricity production [26-29], air conditioning [30-33] and process heat applications [34-36]. All these areas of the solar energy will help solve global energy crises, save money and reduce bills because the sun is a free and clean source of energy.

To be able to use solar thermal energy well, solar collectors should be used, where these collectors are designed to capture the heat coming from the sun by absorbing solar irradiance. The solar collector is a device that converts the solar energy into more usable and storage thermal energy, where the solar irradiance intensity that is concentrated on the absorber area is controlled by the optical properties of the collector, the collector dimensions, the geographical and climatic conditions of the device installation location. There are many types of solar thermal collectors such as the compound parabolic collectors (CPCs) [37], the evacuated tube collectors (ETCs) [38], the Flat-plate collectors (FPCs) [39], the Heliostat field collectors (HFCs) [40], the linear Fresnel reflectors (LFRs) [41], the parabolic dish reflector (PDRs) [42,43] and the parabolic trough collectors (PTCs) [44-46]. Currently, there is a lot of valuable scientific researches aimed at using nanofluid technologies to improve thermal efficiency in solar collectors, because nanoparticles work on improving convection heat transfer coefficient [47] as evidenced by studies carried out by Said et al. [48-55], Mebarek-Oudina and Makinde [56], Raza et al. [57], Alkasassbeh et al. [58] and Mebarek-Oudina [59]. This is a set of scientific researches that have proven successful in using nanofluid technologies to increase the thermal performance in many technological fields including the solar equipment.

This paper was recommended for publication in revised form by Regional Editor Tolga Taner

1Department of Mechanical Engineering, University of Blida 1, Algeria

${ }^{2}$ College of Engineering - Mechanical Engineering Department - University of Babylon - Babylon City - Hilla - Iraq

${ }^{3}$ Mechanical Engineering Department, King Fahd University of Petroleum and Minerals, Dhahran, Saudi Arabia

${ }^{4}$ School of Architecture and Civil Engineering, Northeast Petroleum University, Fazhan Lu Street, Daqing 163318, China

${ }^{\star}$ E-mail address: ghodbanemokhtar39@yahoo.com

Orcid ID: 0000-0003-1350-8631*, 0000-0002-1947-6397, 0000-0002-4360-0159, 0000-0001-9266-408X, 0000-0002-2692-9091

Manuscript Received 19 May 2019, Accepted 21July 2019 
The subject of this study is related to Parabolic Trough Collectors (PTCs). This type contains a circular receiver tube with a suitable selective layer. This tube is surrounded by a glass envelope located along the focal line of the reflector [60,61]. This collector has been used as a device for concentrating the solar energy; so the only directnormal solar irradiance "DNI, "W/m ${ }^{2 "}$ " is used [61]. Since the reflective mirrors follow the sun according to a monosouth-north axis where the solar irradiance is vertical on the reflective mirror, an unused distance between two parallel rows of this solar reflector type should be left within the same solar field in order to maintain a high optical efficiency of the solar device.

In the literature, many studies have dealt with this type of solar concentrates. Firstly, G. K. Manikandan et al. have conducted a review study on the parabolic trough collectors [62], where the aim of their study was to identify ways to enhance and improve the optical and thermal efficiency of this solar collector category. Korres et al. utilized the nanofluids as a heat transfer fluid with a laminar flow at the receiver tube level of the compound parabolic trough solar collector (CPTC) [60]. It was also found that Azzouzi et al. have conducted an experimental study of a parabolic trough collector with large rim angle, which it was made in the Mechanics Department of Khemis Miliana University at Algeria. The authors discussed the optical behavior part of the experimental device [63]. In 2010 [64], FernandezGarcia et al. carried out a study on the numerous parabolic trough reflectors uses. In addition, R. K. Donga and S. Kumar [65], have assessed the heat efficiencies of parabolic trough concentrator with receiver tube, where this tube had a suspicion of alignment and slope. Moreover, Bellos and Tzivanidis have conducted a study on substitute designs for parabolic trough reflectors [44]. In another scientific work, Bellos et al. have completed a study on the effect of the internal fins number in receiver tube of parabolic trough concentrator on changing the thermal efficiencies [66]. In addition, Bellos et al. have conducted a study on the possibility of improving the thermal efficiency of the PTCs reflectors by using cylindrical longitudinal inserts in different positions within the receiver tube [67].There are many other scientific works that Bellos have done in the field of parabolic trough concentrators, aiming to improve the thermal efficiency of this effective technology [68-75]. Besides, recently Moloodpoor et al. studied the thermal behavior of parabolic trough reflectors based on the intelligence swarm enhancer [76].

This study aims to conduct a thermal examination of a small parabolic trough solar reflector where this investigation has been done depending on the numerical solution method. The considered reflector has been studied according to the one-dimension model in a transient regime. The mathematical model governing the heat transfer phenomenon at the receiver tube is based on the conservation laws of energy and mass through the different surfaces establishing the receiver. Pure water has been used as a carrier fluid for heat, as it changes according to climatic conditions of El-Oued region on 16 March 2018. All thermal coefficients that have been affected by the thermal behavior of the studied solar system have been carefully identified. The results obtained from the present study will allow giving a clear idea about the possibility of using this solar dispositive in many fields depending on the final heat transfer fluid temperature when it is released from the absorber tube.

Currently, the research team manufactures a solar center with dimensions and characteristics listed in Tables (1) and (2). The Matlab program, which has been completed, has demonstrated the efficiency and credibility of its results in previous scientific research (experimental and numerical) $[9-11,77,8]$, so the research team to proceed with conducting this study, which relies on the numerical simulation. This paper considered the thermal coefficients that affected the thermal efficiency of the studied device. As is known these thermal coefficients are very complex, and is not easily determined with great precision, but in this study, they have been successfully followed step by step.

\section{THERMAL STUDY}

Numerical simulation has been used as a means of tracking thermal behavior at the level of the solar system. The simulation is based on an energy balance between the components of the copper receiver tube. The energy balance for the copper receiver tube, the fluid heat carrier and the glass envelope are considered independently. Figs. 1(a) and 1(b) show the dimensions of the studied reflector. 


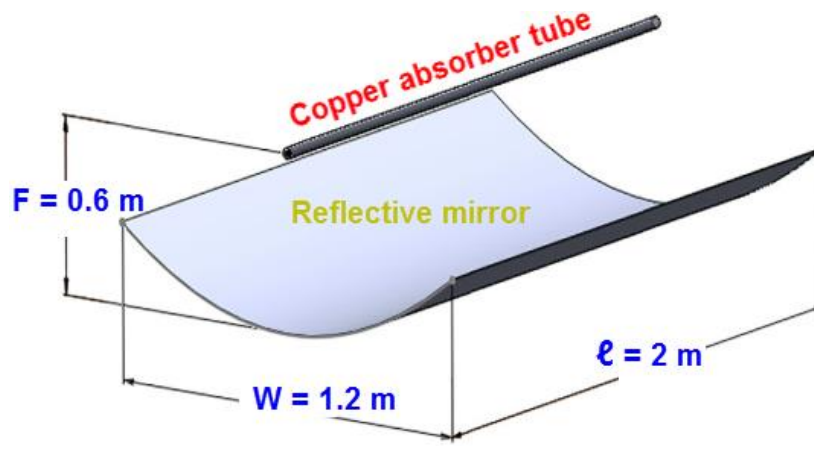

(a)

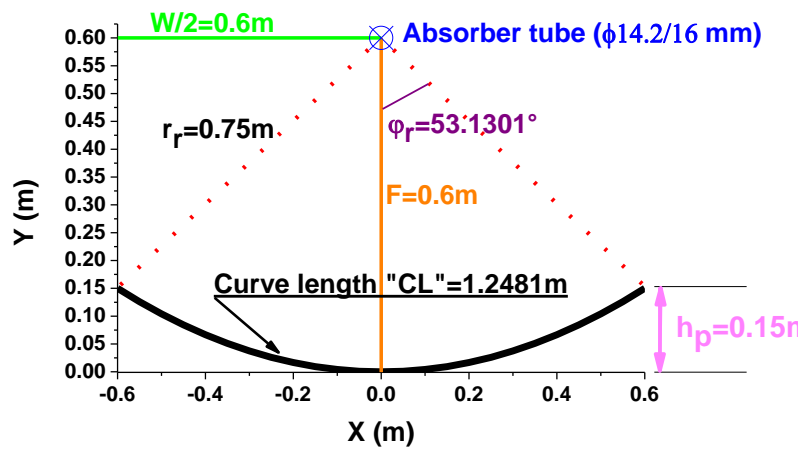

(b)

Figure 1. Engineering description of the studied solar reflector: a) General appearance [67], b) Cross-section.

As previously stated, the main objective of this work is to make a thermal investigation on the studied concentrator according to the geometrical parameters of the concentrating elements. This examination will enable the identification of the intensity of the heat flux on the receiver surface. In addition, It will be estimated the thermal efficiency " $\eta_{\mathrm{th}}$ ", the receiver tube temperature " $\mathrm{T}_{\mathrm{Ab}},\left({ }^{\circ} \mathrm{C}\right)$ ", the fluid temperature " $\mathrm{T}_{\mathrm{HTF}}$, $\left({ }^{\circ} \mathrm{C}\right)$ ", the glass tube temperature " $\mathrm{T}_{\mathrm{G}},\left({ }^{\circ} \mathrm{C}\right)$ " and the overall coefficient of the thermal loss " $\mathrm{U}_{\mathrm{L}},\left(\mathrm{W} / \mathrm{m}^{2 \circ} \mathrm{C}\right)$ ". Therefore, the thermal behavior has been determined based on these assumptions:

- The thermal fluid is incompressible;

- The parabola shape is symmetrical;

- The ambient air temperature around the concentrator is uniform;

- The effect of the tube shadow on the mirror is negligible;

- The solar flux at the receiver is uniformly distributed;

- The glass tube is considered opaque to infrared radiation;

- The conduction exchanges in the receiver tube and the glass tube are negligible.

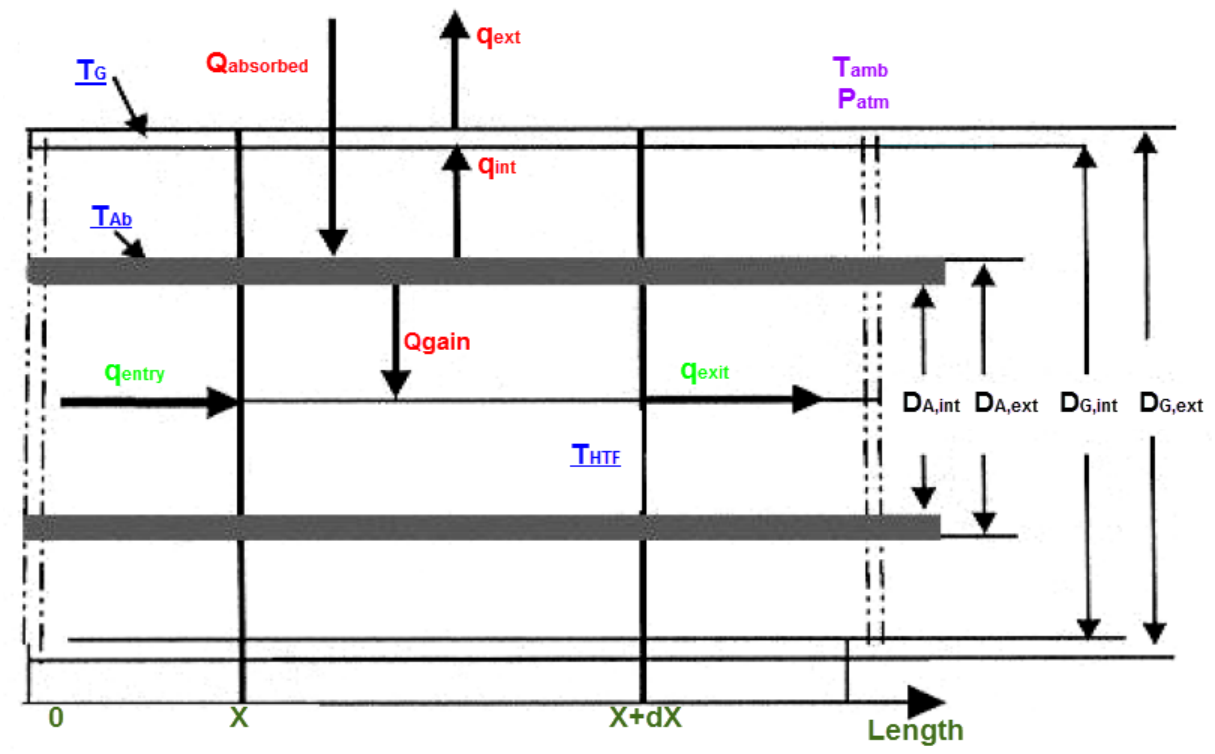

Figure 2. The energy balance at the receiver tube [26].

For the thermal analysis, it is necessary to derive appropriate expressions for the mirror efficiency factor " $F$ ", the thermal loss coefficient " $\mathrm{U}_{\mathrm{L}}$ " and the heat dissipation factor " $\mathrm{F}_{\mathrm{R}}$ " of the collector. 
The collector thermal efficiency can be calculated according to Eq. $1[67,78,77,8]$. This factor represents the ratio between the thermal energy acquired by fluid "Qgain, (W)" transmitted to the heat transfer fluid and the power "Qs, (W)", where "Qs, (W)" is the amount of the solar energy that reaches the reflective mirror and then reflected towards the receiver tube. In addition, "Q, $(\mathrm{W})$ " is representing the direct normal solar irradiance "DNI, (W/m²)" multiplied by the effective collector area " $\mathrm{A}_{\mathrm{a}},\left(\mathrm{m}^{2}\right)$ ".

$$
\eta_{t h}=\frac{Q_{\text {gain }}}{Q_{S}}=\frac{Q_{\text {gain }}}{D N I \cdot A_{a}}
$$

Where, the useful heat supplied to the fluid can be calculated by $[67,78,77,8]$ :

$$
Q_{\text {gain }}=Q_{m} \cdot C_{p}\left(T_{S}-T_{i}\right)
$$

With the mass flow " $\mathrm{Q}_{\mathrm{m}},(\mathrm{kg} / \mathrm{s})$ " equals to $0.015 \mathrm{~kg} / \mathrm{s}$. It can also be computed " $\mathrm{Q}_{\text {gain, }},(\mathrm{W})$ "

by Eq. $3[78]$.

$$
Q_{\text {gain }}=F_{R}\left[\eta_{o p t} \cdot D N I \cdot A_{a}-U_{L} \cdot A_{r, \text { ext }} \cdot\left(T_{i}-T_{a m b}\right)\right]
$$

As for " $F_{R}$ " is the heat dissipation factor, it can be calculated by Eq. 4 [78].

$$
F_{R}=\frac{Q_{m} \cdot C_{p}}{A_{r, \text { ext }} \cdot U_{L}}\left[1-e^{\left(\frac{A_{r, \text { ext }} \cdot U_{L} \cdot F \prime}{Q_{m} \cdot C_{p}}\right)}\right]
$$

Mirror efficiency factor "F" can be determined from Eq. 5 [78].

$$
F^{\prime}=\frac{\frac{1}{U_{L}}}{\frac{1}{U_{L}}+\frac{D_{A, \text { ext }}}{h_{F} D_{A, \text { int }}}+\left(\frac{D_{A, \text { ext }}}{2 k_{F}} \operatorname{Ln} \frac{D_{A, \text { ext }}}{D_{A, \text { int }}}\right)}
$$

$" \mathrm{~h}_{\mathrm{F}},\left(\mathrm{W} / \mathrm{m}^{2 \circ} \mathrm{C}\right)$ " illustrates the heat transfer coefficient of the heat transfer fluid inside the receiver tube. It can be determined from Eq. 6 [78].

$$
h_{F}=\frac{N u_{F} \cdot k_{F}}{D_{A, i n t}}
$$

The water flow regime in this paper is laminar, so the details of the calculation of fluid Nusselt Number "Nu" are somewhat lengthy, but are detailed in Ref. [9].

The overall coefficient of thermal loss can be calculated by Eq. 7 [78].

$$
U_{L}=\left[\frac{A_{r, \text { ext }}}{\left(h_{w}+h_{r, G-a}\right) A_{G, e x t}}+\frac{1}{h_{r, r-G}}\right]^{-1}
$$

The optical efficiency is given by [78]:

$$
\eta_{o p t}=\rho_{m} \cdot \gamma \cdot \tau \cdot \alpha_{A b} \cdot K\left(\theta_{i}\right)
$$


When calculating the optical efficiency of this device must take into account all the optical errors of different types. $\mathrm{K}\left(\theta_{\mathrm{i}}\right)$ is one of the important optical coefficients, as it is a coefficient that corrects the incidence angle " $\theta_{\mathrm{i}},\left(^{\circ}\right)$ " of the arrival of the direct normal irradiance into the reflective mirror. This coefficient is called the incidence angle modifier coefficient, it can determined from Eq. 9 [61, 79].

$$
K\left(\theta_{i}\right)=1-\frac{F}{\ell}\left[\left(1+\frac{W^{2}}{48 F^{2}}\right) \tan \left(\theta_{i}\right)\right]
$$

$" \mathrm{~h}_{\mathrm{w}},\left(\mathrm{W} / \mathrm{m}^{2 \circ} \mathrm{C}\right)$ " is the convective exchange coefficient between the glass cover and the ambient air, it can be calculated by Eq. (10) [78].

$$
h_{w}=\frac{N u_{a i r} \times k_{\text {air }}}{D_{G, \text { int }}}
$$

As for "Nuair" is the air Nusselt number. It is a dimensionless coefficient used to characterize the convective thermal transfers between a fluid and a wall. This parameter can be calculated in terms of the fluid flow regime. This parameter can be calculated by Eq. 11 .

$$
N u_{\text {air }}=\left\{\begin{array}{c}
0.40+0.54 R e^{0.52} \text { for } 0.1 \leq R e \leq 1000 \\
0.30 R e^{0.60} \text { for } 1000<R e \leq 50000
\end{array}\right.
$$

With "Re" represents the air Reynolds number. This coefficient is defined by Eq. 12 [78].

$$
R e=\frac{\rho_{\text {air }} \cdot W_{S} \cdot D_{G, e x t}}{\mu_{\text {air }}}
$$

With regard to " $\mathrm{h}_{\mathrm{r}, \mathrm{G}-\mathrm{a}},\left(\mathrm{W} / \mathrm{m}^{2 \circ} \mathrm{C}\right)$ ", it is the radiative exchange coefficient between the glass cover and the ambient air. It is given by [78]:

$$
h_{r, G-a}=\varepsilon_{G} \cdot \sigma\left(T_{G}+T_{a m b}\right)\left(T_{G}^{2}+T_{a m b}^{2}\right)
$$

For the coefficient " $\mathrm{h}_{\mathrm{r}, \mathrm{r}-\mathrm{G}},\left(\mathrm{W} / \mathrm{m}^{2 \circ} \mathrm{C}\right)$ ", it shows the radiative exchange factor between the receiver tube and the glass tube. It is defined by Eq. 14 [78].

$$
h_{r, r-G}=\frac{\sigma \cdot\left(T_{G}+T_{A b}\right)\left(T_{G}^{2}+T_{A b}^{2}\right)}{\frac{1}{\varepsilon_{G}}+\frac{A_{r, e x t}}{A_{G}}\left(\frac{1}{\varepsilon_{G}}-1\right)}
$$

\section{RESULTS AND DISCUSSION}

\section{Dimensions and Device Features}

The parabolic trough concentrator has a parabolic reflective mirror arranged in a cylindrical manner. This geometry makes it possible to focus the direct-normal irradiance along a linear generator in which is placed an absorber tube which circulates the heat transfer fluid. Table (1) shows the Optical characteristics of the studied PTC collector. 
Table 1. Optical characteristics of studied solar concentrator [80].

\begin{tabular}{|l|c||l|c|}
\hline \multicolumn{1}{|c|}{ Parameter } & Value & \multicolumn{1}{|c|}{ Parameter } & Value \\
\hline Overall average optical error $\left(\mathrm{O}_{\text {perror }}\right)$ & $03 \mathrm{mrad}$ & Absorption coefficient of the absorber $\left(\alpha_{\mathrm{Ab}}\right)$ & 0.94 \\
\hline Mirror reflection coefficient $\left(\rho_{\mathrm{m}}\right)$ & 0.92 & The emissivity of the absorber tube $\left(\varepsilon_{\mathrm{Ab}}\right)$ & 0.12 \\
\hline Transmissivity of the glass cover $(\tau)$ & 0.945 & The emissivity of the glass $\left(\varepsilon_{\mathrm{G}}\right)$ & 0.935 \\
\hline
\end{tabular}

The PTC collector usually provided with a solar tracking to adapt the reflector inclination, as the beam radiation is always perpendicular to the PTC opening area. As for the PTC receiver tube, it is the main component of the considered concentrator, whose function is to absorb the direct normal irradiance, to convert it into heat and transmit this heat to a heat transfer fluid. The dimensions shown in Table (2) are dimensions of a solar collector currently manufactured by the research team of Ghodbane and his colleagues.

Table 2. Geometric characteristics of studied solar concentrator.

\begin{tabular}{|l|c||l|c|}
\hline \multicolumn{1}{|c|}{ Geometric feature } & Value & \multicolumn{1}{c|}{ Geometric feature } & Value \\
\hline Outer diameter of the absorber $\left(\mathrm{D}_{\mathrm{A}, \mathrm{ext}}\right)$ & $0.016 \mathrm{~m}$ & Opening width of the reflective mirror $(\mathrm{W})$ & $1.2 \mathrm{~m}$ \\
\hline Inner diameter of the absorber $\left(\mathrm{D}_{\mathrm{A}, \mathrm{int}}\right)$ & $0.0142 \mathrm{~m}$ & Curve length of the reflective mirror $(\mathrm{CL})$ & $1.2481 \mathrm{~m}$ \\
\hline Outer diameter of the glass $\left(\mathrm{D}_{\mathrm{G}, \mathrm{ext}}\right)$ & $0.02 \mathrm{~m}$ & Rim angle $\left(\varphi_{\mathrm{r}}\right)$ & $53.1301^{\circ}$ \\
\hline Inside diameter of the glass $\left(\mathrm{D}_{\mathrm{G}, \mathrm{int}}\right)$ & $0.0175 \mathrm{~m}$ & Rim radius $\left(\mathrm{r}_{\mathrm{r}}\right)$ & $0.75 \mathrm{~m}$ \\
\hline Mirror length $(\ell)$ & $2 \mathrm{~m}$ & Focal distance $(\mathrm{F})$ & $0.6 \mathrm{~m}$ \\
\hline
\end{tabular}

Finally, a computer program has been developed to simulate the thermal performance of the studied reflector, where this program is written in Matlab language.

\section{Climatic Conditions}

Fig. 3 shows the solar irradiance evaluation from sunrise to sunset for the day of March 16, 2018 in the

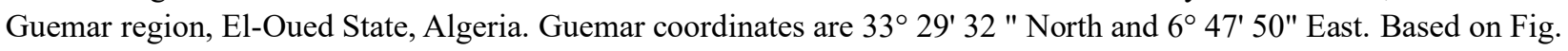
3 , it is noted that the maximum value of the total solar irradiance reached $1202.81 \mathrm{~W} / \mathrm{m}^{2}$ at $10: 50$, and the minimum value reached $5.4 \mathrm{~W} / \mathrm{m}^{2}$ at 19:00. It is also noticeable that there are some clouds between 11:30 and 15:00.

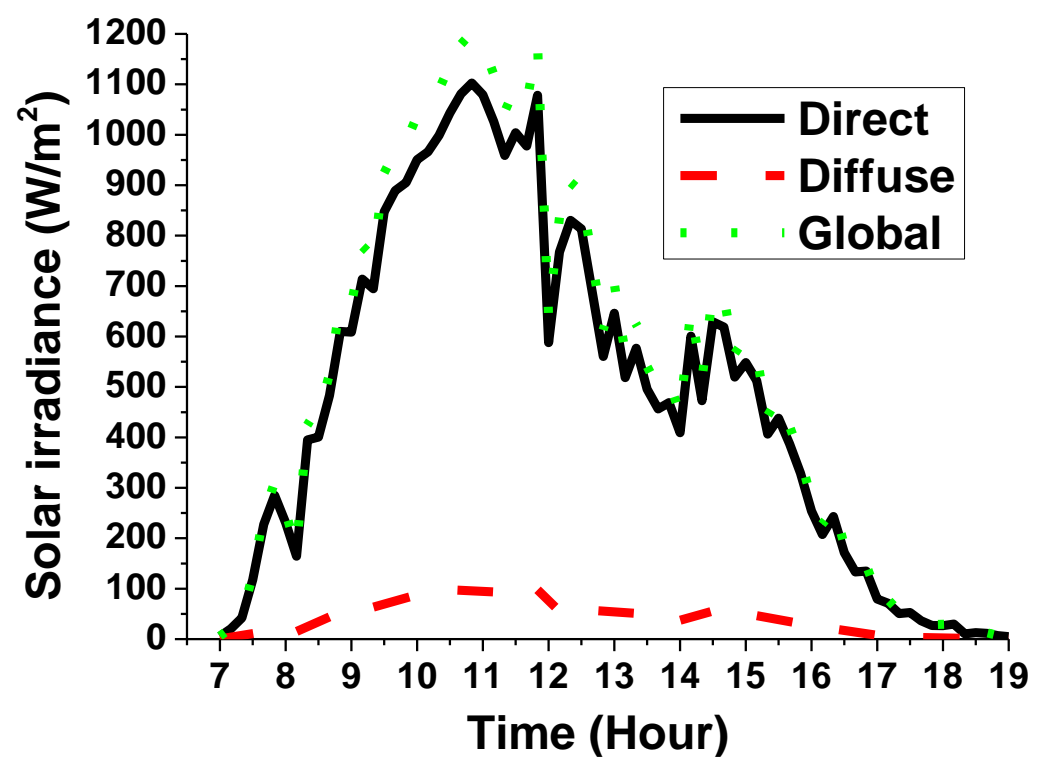

Figure 3. Measured values of solar irradiance $\left(\mathrm{W} / \mathrm{m}^{2}\right)$. 
The amount of the solar irradiance for the studied day is very high. This strong motive encourages the thought of creating fields for solar collectors in order to exploit the sun's energy in many fields such as electricity production or desalination.

Fig. 4 shows the change in the ambient air temperature and the wind speed. The maximum air temperature reached $29.85{ }^{\circ} \mathrm{C}$ at 08:50, and the minimum value was $22.75{ }^{\circ} \mathrm{C}$ at $07: 30$. With regard to the wind speed, its peak reached $8.7 \mathrm{~m} / \mathrm{s}$ in the evening between 16:00 and 18:00. Therefore, this wind speed will not affect the optical efficiency of the solar field because it is close to the sunset. As for the minimum wind speed is $4.1 \mathrm{~m} / \mathrm{s}$, this value was recorded between 10:00 and 12:00.

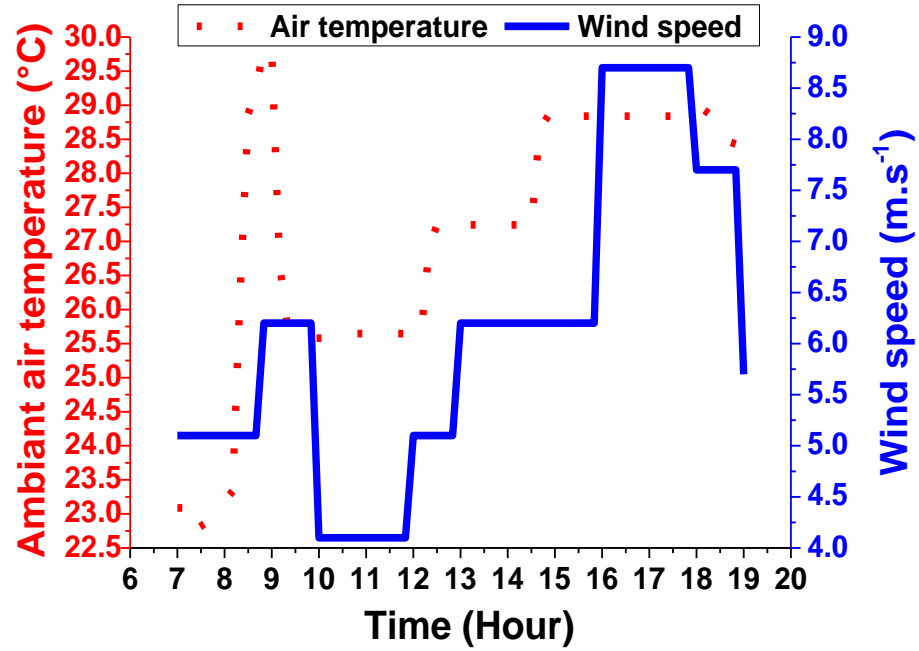

Figure 4. Measured values of the ambient air temperature and the wind speed.

\section{Thermal Analysis of the Device}

There are many important parameters involved in determining the thermal efficiency of any solar system. Fig. 5 shows changes in the heat dissipation factor $\left(F_{R}\right)$ and the mirror efficiency factor $\left(F^{\prime}\right)$ versus time for the studied day from the sunrise to sunset. The mirror efficiency coefficient $\left(F^{\prime}\right)$ illustrates the fraction of the actual useful energy gain to the useful energy gain that would result if the reflector-absorbing area had been at the local fluid temperature. It represents the heat transfer resistance from the fluid to the ambient air. With regard to the heat removal coefficient $\left(F_{R}\right)$, it represents the ratio value of the actual useful power gain that would result if the concentrator-absorbing area had been at the local fluid temperature. Through Fig. 5, it is noted that:

- The maximum, minimum, and mean values for mirror efficiency factor are 0.9863 at 07:00 and 19:00, 0.981 at $10: 50$ and 0.9844 , respectively;

- The maximum, minimum, and mean values for heat removal coefficient are 0.9769 at 07:00 and 19:00, 0.9599 at $10: 50$ and 0.9701 , respectively;

- The two parameters change in parallel, but the values of $\left(F^{\prime}\right)$ are slightly higher than $\left(F_{R}\right)$. As shown in Eqs. 4 and 5, both factors change in reverse with the change of the overall coefficient of thermal loss " $\mathrm{U}_{\mathrm{L}}$ ".

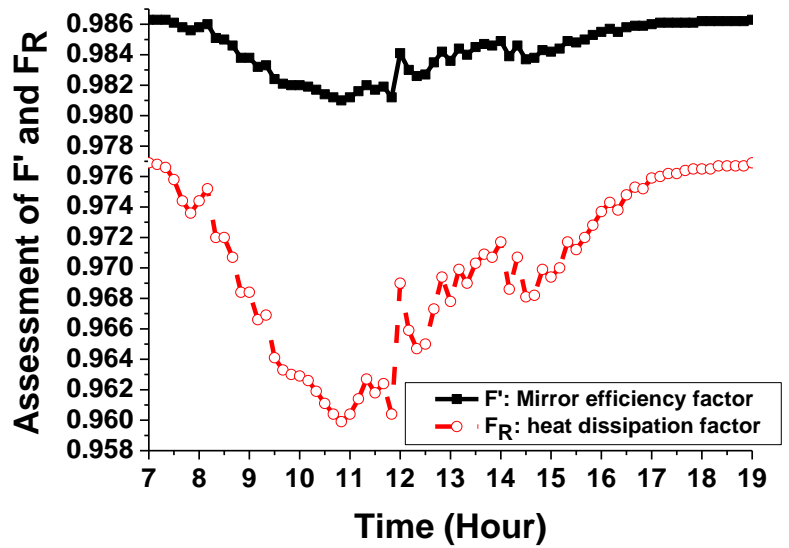

Figure 5. Evaluation of the heat dissipation factor $\left(F_{R}\right)$ and the efficiency factor of the mirror $\left(F^{\prime}\right)$. 
In addition, the curves of Fig. 5 show the reasonable results obtained by the numerical simulation, which accurately applauds the results obtained. Changing climate conditions has a direct effect on these two important factors in determining the thermal behavior at the receiver tube level of the studied device.

Generally, solar concentrators (punctual or linear) have optical properties that vary substantially with the geometry of the device. In addition, the change in the geometric structure and optical properties of the solar reflector elements directly affects the collector optical efficiency. Fig. 6 shows the evolution of the optical and thermal efficiencies of the studied reflector. As for the optical efficiency, its average value is $78.55 \%$, while the mean value of the thermal efficiency is $74.30 \%$.

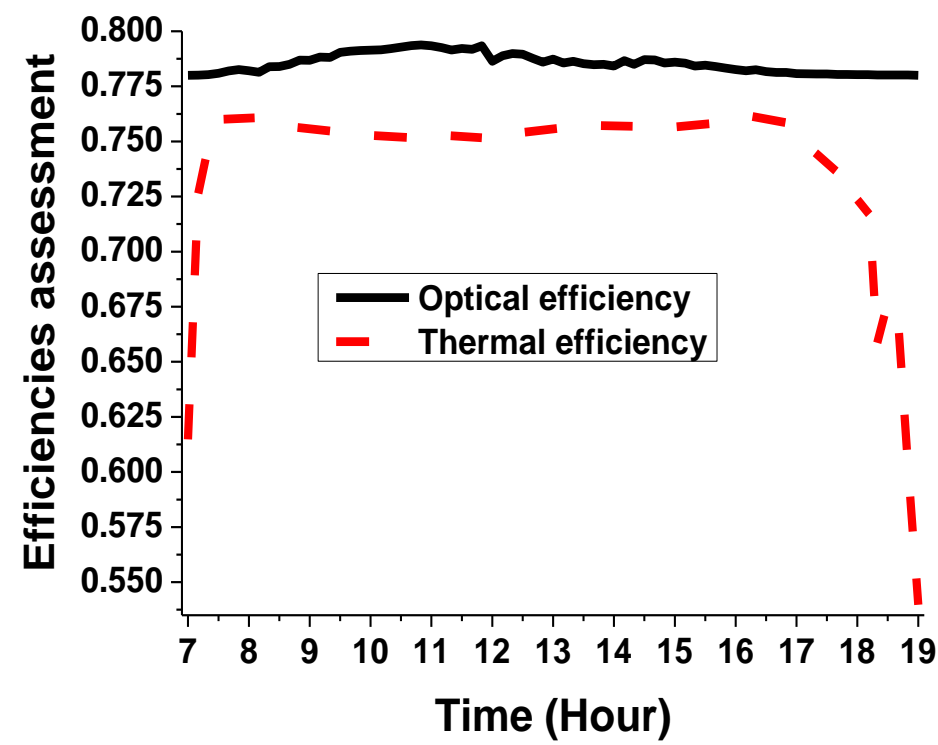

Figure 6. Evaluation of the efficiencies versus time.

As indicated in Eq. 8, many factors control the reflector optical efficiency. These factors straight relate to the optical properties of the solar reflector elements (design and configuration) and directly affect by the environment handling (dust, errors, etc.). The optical factors that affect the concentrator efficiency are:

- The interception factor " $\gamma$ " expressed by the direct-normal solar irradiance ration that is reflected on reflective mirrors in order to concentrate on the receiver tube;

- The mirror reflectance " $\rho_{\mathrm{m}}$ " is the ratio of the reflected solar radiation to incident solar radiation in the ideal case, i.e. the reflective mirror is perfectly clean;

- The glass tube transmittance coefficient " $\tau$ " is the ratio of transmitted solar radiation to incident solar radiation in the ideal case, i.e. the glass tube is perfectly clean;

- The absorption coefficient of the receiver tube " $\alpha_{\mathrm{Ab}}$ " is the ratio of the absorbed solar radiation to incident solar radiation in the ideal case.

These optical parameters have a direct impact on the solar reflector efficiency, where the optical efficiency calculating will allow identification the solar radiation ratio that is absorbed by the receiver tube, but there is always a quantity of the thermal energy in the form of loss "Q $\mathrm{Q}_{\text {lost}}$, (Ws)".

For the parabolic trough solar reflector, the thermal losses are due to the temperature difference between the receiver tube, the glass cover tube and the environment. The lost power " $\mathrm{Q}_{\text {lost, }}(\mathrm{W})$ " is proportional to the temperature difference of the receiver tube and the ambient air. In general, the transparent cover glass is used to reduce the convective loss between the receiver tube and the ambient air, especially when the medium confined between the glass and the receiver tube is a vacuum medium. It also reduces the concentrator's radiation losses because the glass is transparent to the short-wave radiation received by the sun, but it is almost opaque to the long-wave heat radiation emitted by the absorber tube (greenhouse effect). Fig. 7 illustrates the change in thermal loss coefficients versus time. 


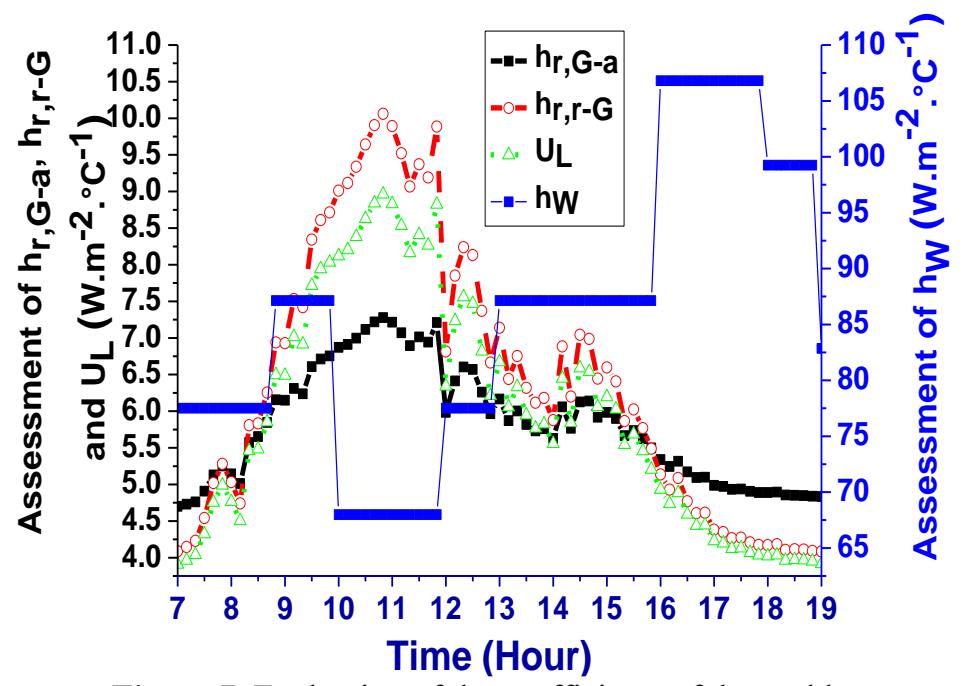

Figure 7. Evaluation of the coefficients of thermal losses.

As it is observed from Fig. 7, the heat loss coefficients vary according to climatic conditions and according to the temperature change of the heat transfer fluid flowing inside the receiver tube. Table (3) contains a summary of the change in heat loss coefficients.

Table 3. Assessment of the thermal loss coefficients.

\begin{tabular}{|c|c|c|c|}
\hline Coefficient & Maximum value & Minimum value & Average daily \\
\hline $\mathrm{h}_{\mathrm{w}}\left(\mathrm{W} / \mathrm{m}^{2 \circ} \mathrm{C}\right)$ & 106.8 & 67.99 & 85.98 \\
\hline $\mathrm{h}_{\mathrm{r}, \mathrm{r} G \mathrm{G}}\left(\mathrm{W} / \mathrm{m}^{2 \circ} \mathrm{C}\right)$ & 10.06 & 4.085 & 6.39 \\
\hline $\mathrm{h}_{\mathrm{r}, \mathrm{G} \mathrm{a}}\left(\mathrm{W} / \mathrm{m}^{2 \circ} \mathrm{C}\right)$ & 7.277 & 4.701 & 5.82 \\
\hline $\mathrm{U}_{\mathrm{L}}\left(\mathrm{W} / \mathrm{m}^{2 \circ} \mathrm{C}\right)$ & 8.963 & 3.909 & 5.96 \\
\hline
\end{tabular}

The heat losses reduction at the receiver tube can be achieved by using a selective surface to reduce the heat transfer losses by the radiation or by removing the thermal convection causes by using an annular space between the receiver tube and the glass tube.

Fig. 8 shows the evaluation of the useful energy gain and the lost energy versus time. It is noted that during the studied day, the useful power gain absorbed by the heat transfer fluid and the lost power to the external environment are changed under the influence of climatic parameters.

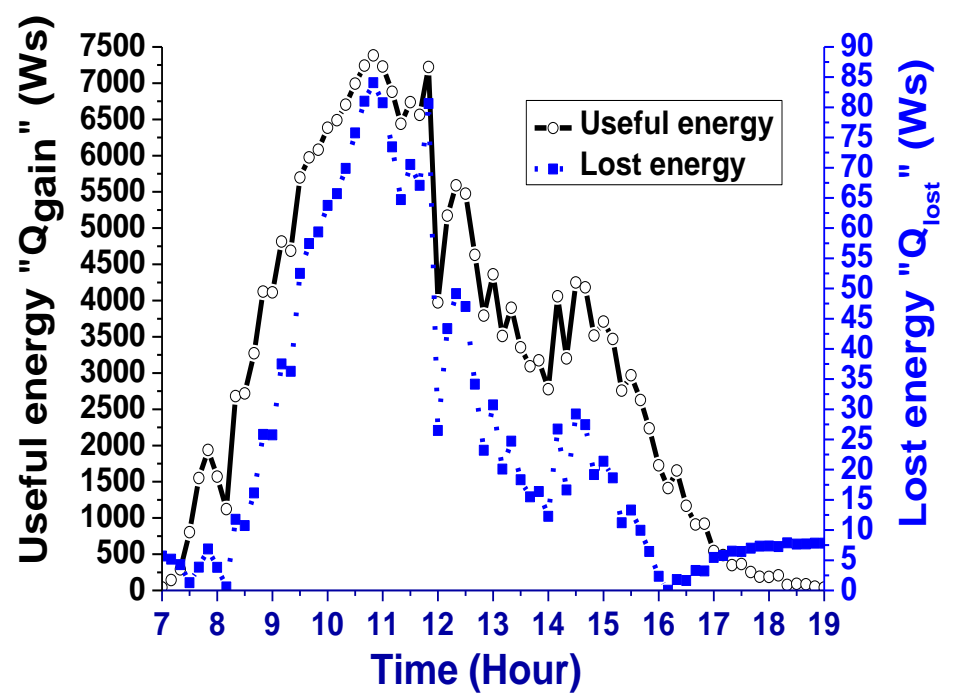

Figure 8. Evolution of the useful and lost energy. 
Therefore, the useful energy gain evolution is sensitive to the direct-normal solar irradiance variation and to the optical characteristics of the solar reflector elements. Table (4) summarizes the change in the energy around the solar collector elements.

Table 4. Assessment of energy change.

\begin{tabular}{|c|c|c|c|}
\hline Energy & Maximum value & Minimum value & Average daily \\
\hline Useful energy gain (Ws) & 7382 & 38.25 & 3210.78 \\
\hline Lost energy (Ws) & 84.08 & 0.02643 & 26.14 \\
\hline
\end{tabular}

The change in the energy shown in Fig. 8 can be expressed by changes in temperature for the various components of the studied solar collector, as shown in Fig. 9. The average temperature of water when entering the receiver tube equals to $15.05{ }^{\circ} \mathrm{C}$. The effect of the climatic conditions on the temperature change is very apparent, where the results of Fig. 9 can be summarized in these points:

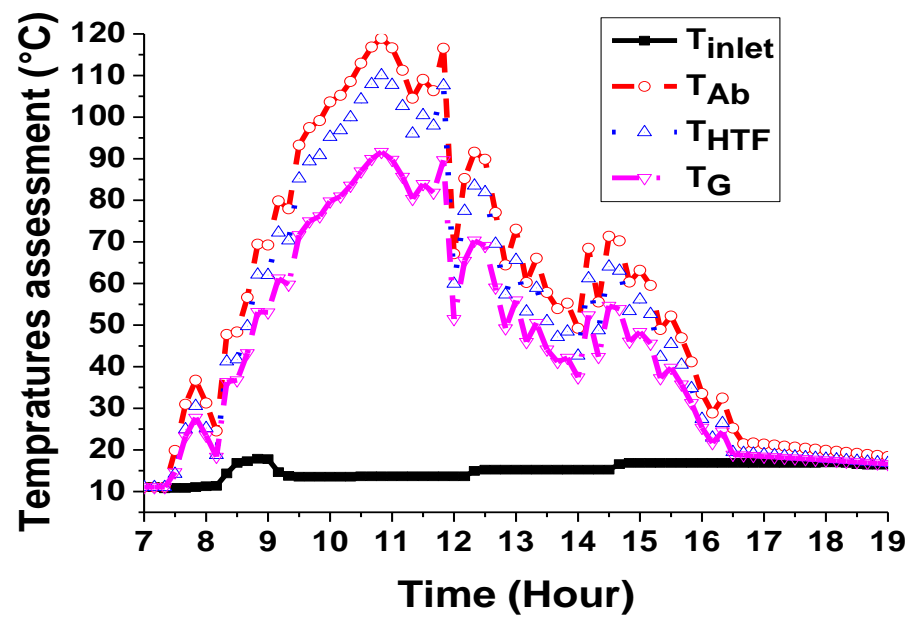

Figure 9. Evaluation of the temperature change.

- The maximum and minimum values for receiver tube temperature are $118.95{ }^{\circ} \mathrm{C}$ at $10: 50$ and $11.05^{\circ} \mathrm{C}$ at sunrise, respectively;

- The maximum and minimum values for the heat transfer fluid temperature are $110.05{ }^{\circ} \mathrm{C}$ at $10: 50$ and $11.05^{\circ} \mathrm{C}$ at sunrise, respectively;

- The maximum and minimum values for the glass tube temperature are $91.65^{\circ} \mathrm{C}$ at $10: 50$ and $11.05^{\circ} \mathrm{C}$ at sunrise, respectively;

- It is noted that the water has changed from a liquid to vapor between 10:20 and 11:50, but the passage of clouds after 10:50 has worked to keep the water in its liquid state but at significant temperatures.

Despite the small size of the studied solar collector, but the temperatures obtained are very significant, this is an evidence of the perceived efficiency of this solar reflector.

To date, there is no direct experimental data describing the local concentration ratio and the distribution of concentrated solar radiation flux on the peripheral receiver tube. The local concentration ratio (LCR) is the ratio between the heat flux density perceived by the receiver tube and the density of the direct-normal solar irradiance.

Fig. 10 represents the LCR distribution on the cross-section of the peripheral receiver tube. In the general case, the local concentration ratio is distributed in the longitudinal direction of the receiver tube on a regular basis (LCR distribution is uniform along the axis $(\mathrm{X})$ ). From the other hand, it is non-uniform in the circumferential direction of the receiver tube, where it is concentrated on the lower part, which faces the reflective mirror of the solar reflector. 
For the upper part, it is very low because on this part, the solar radiation that touches the face is a direct radiation and the face of this part of the tube remains very far from the radiation reflected by the reflective mirror.

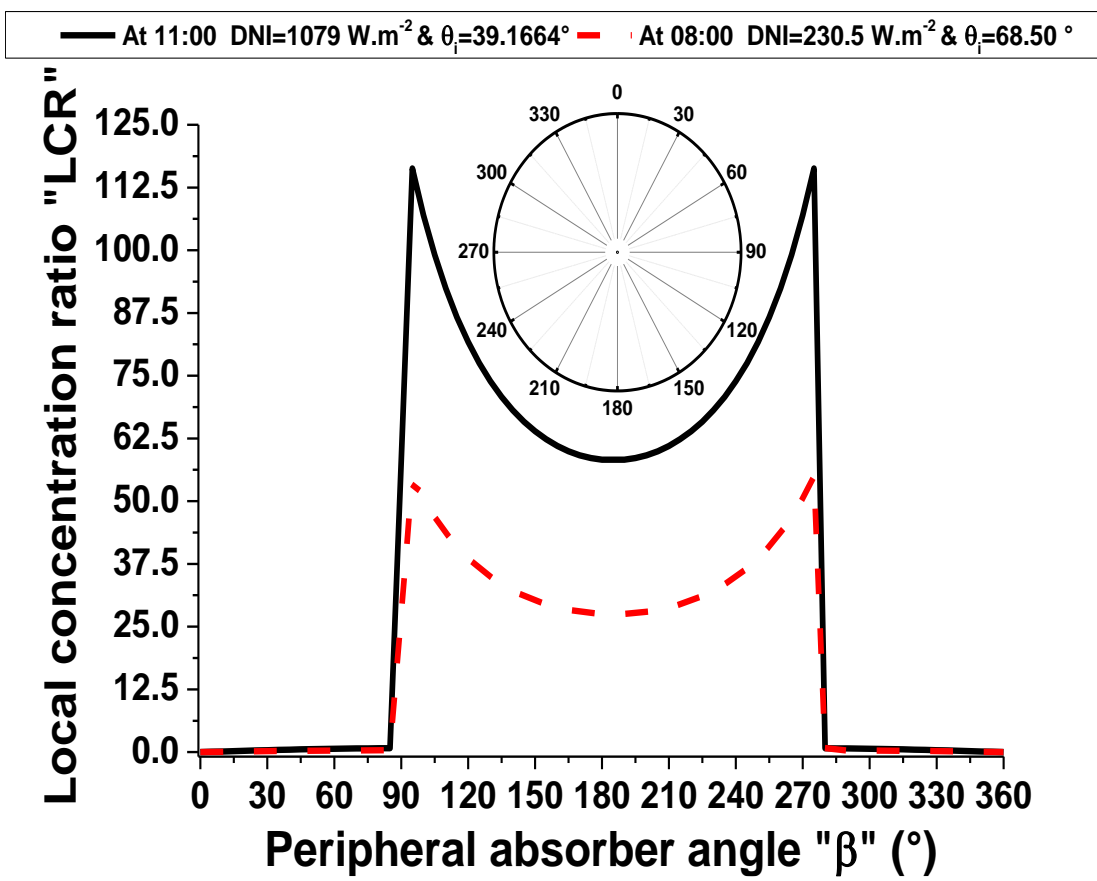

Figure 10. Assessment of the local concentration ration.

When analyzing the results of Fig. 10, it is noted that the climatic conditions, especially the flow of the directnormal solar irradiance, has a direct effect on thermal behavior at the level of the receiver tube, where the solar radiation increases, the local concentration coefficient increases. The same behavior is seen when analyzing Fig. 11. Fig. 11 presents the distribution of the heat flux density on the outer wall of the receiver tube. The gradients of the circumferential heat flux distribution are a consequence of the non-uniformity of the local concentration ratio. Table (5) contains the main points covered by Figs. 10 and 11.

Table 5. Assessment of heat flux distribution on the cross-section of the peripheral receiver tube.

\begin{tabular}{|c|c|c|c|c|c|c|c|c|c|c|c|c|}
\hline \multirow[b]{2}{*}{ Peripheral receiver angle " $\beta,\left({ }^{\circ}\right)$ " } & \multicolumn{6}{|c|}{ Local concentration ratio "LCR" } & \multicolumn{6}{|c|}{ Concentrated energy $\left(\mathrm{W} / \mathrm{m}^{2}\right)$} \\
\hline & 269 & 180 & 91 & 89 & 0 & 271 & 269 & 180 & 91 & 89 & 0 & 271 \\
\hline $\mathrm{DNI}=1079 \mathrm{~W} / \mathrm{m}^{2}$ at $11: 00$ & 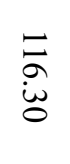 & $\begin{array}{l}u_{1} \\
\dot{u} \\
\dot{u}\end{array}$ & 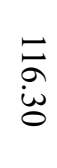 & $\stackrel{\circ}{y}$ & 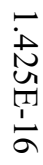 & $\stackrel{\ominus}{\exists}$ & $\begin{array}{l}\bar{N} \\
\stackrel{+}{\infty} \\
+\infty \\
\stackrel{ \pm}{y}\end{array}$ & 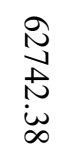 & 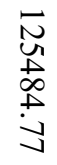 & $\begin{array}{l}\underset{w}{\infty} \\
\underset{\infty}{\infty}\end{array}$ & $\begin{array}{l}\vec{u} \\
\dot{t} \\
\overrightarrow{1} \\
\dot{\omega}\end{array}$ & $\begin{array}{l}\underset{w}{\infty} \\
\underset{\infty}{\infty}\end{array}$ \\
\hline $\mathrm{DNI}=230.50 \mathrm{~W} / \mathrm{m}^{2}$ at $08: 00$ & $\begin{array}{l}\stackrel{y}{+} \\
\dot{\theta}\end{array}$ & $\begin{array}{l}\stackrel{N}{A} \\
\vec{B}\end{array}$ & $\begin{array}{l}\stackrel{u}{+} \\
\dot{i}\end{array}$ & $\begin{array}{l}\text { i } \\
\text { ă }\end{array}$ & 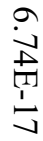 & 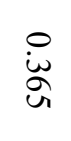 & $\begin{array}{l}\bar{N} \\
\stackrel{\Xi}{0} \\
\underset{\infty}{\infty}\end{array}$ & $\begin{array}{l}\underset{w}{w} \\
\stackrel{\sim}{0} \\
\dot{\sigma}\end{array}$ & $\begin{array}{l}\bar{N} \\
\stackrel{\sigma}{0} \\
i \\
i \\
\infty\end{array}$ & $\stackrel{\infty}{\stackrel{\infty}{\dot{\omega}}}$ & $\begin{array}{l}\overrightarrow{\dot{u}} \\
\dot{\mu} \\
\overrightarrow{1} \\
\vec{\Delta}\end{array}$ & $\begin{array}{l}\underset{\omega}{\infty} \\
\dot{\infty} \\
\dot{\infty}\end{array}$ \\
\hline
\end{tabular}


The results shown in Table (5) give an idea of the real thermal behavior at the receiver tube level versus real climatic conditions.

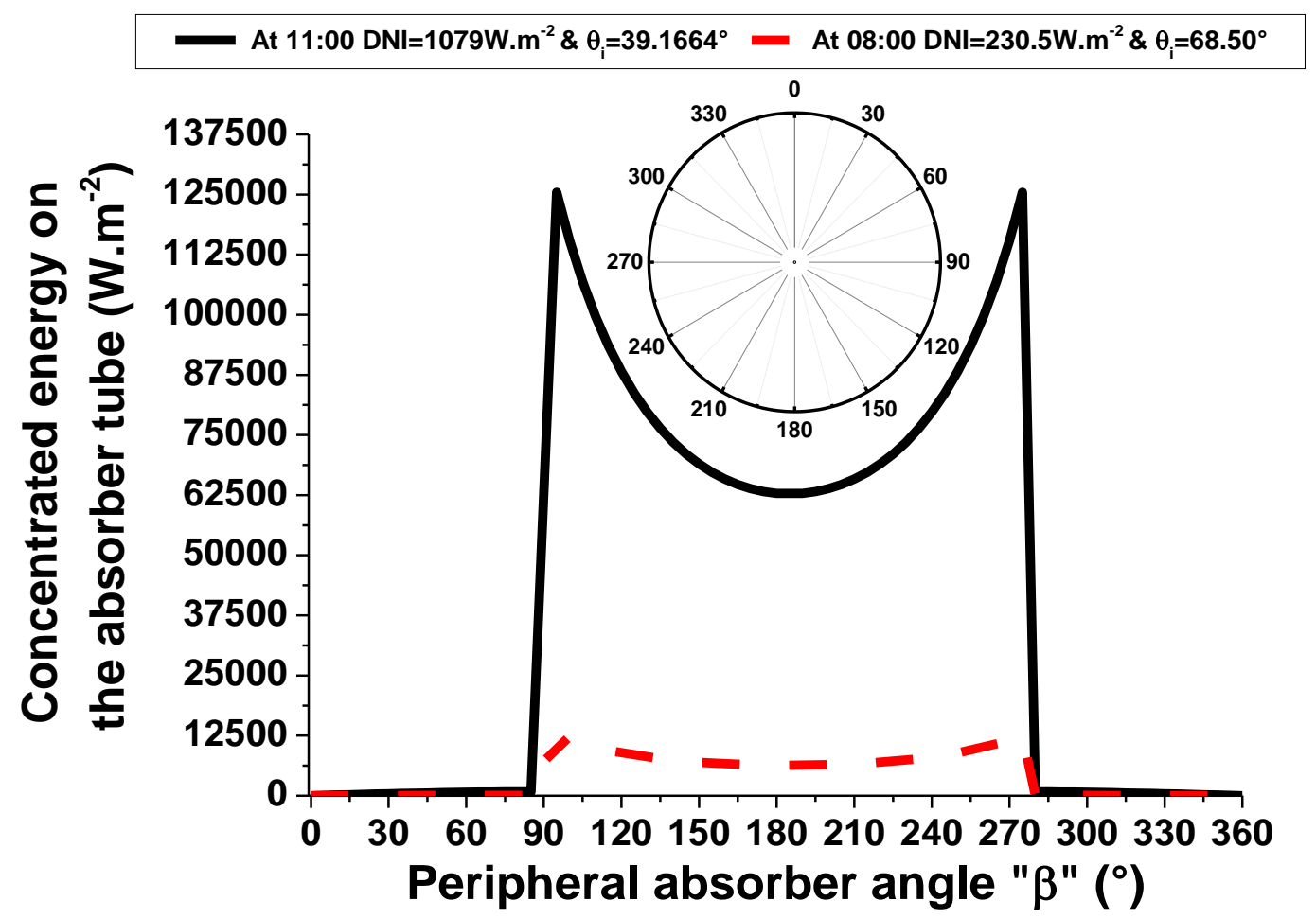

Figure 11. Assessment of the concentrated energy on the receiver tube.

\section{CONCLUSIONS}

This study is devoted to the investigation of the parabolic trough concentrator in order to estimate its thermal performances according to the geometrical, optical and climatic parameters in the region of El-Oued, Algeria for the day of $16 / 03 / 2018$. Pure water was chosen as a heat transfer fluid. This thermal investigation was carried out by using the energy balance equations, which were analyzed using the numerical method. The main elements of the thermal behavior that have been covered are:

- The thermal efficiency, which has an average value of $74.30 \%$;

- The absorber tube temperature, which has a maximum value of $118.95^{\circ} \mathrm{C}$ and a minimum value of $11.05^{\circ} \mathrm{C}$;

- The heat transfer fluid temperature, which has a maximum value of $110.05^{\circ} \mathrm{C}$ and a minimum value of $11.05^{\circ} \mathrm{C}$;

- The glass tube temperature, which has a maximum value of $91.65^{\circ} \mathrm{C}$ and a minimum value of 11.05 ${ }^{\circ} \mathrm{C}$;

- The heat transfer coefficient of heat transfer fluid, which has an average value of $948.65 \mathrm{~W} / \mathrm{m}^{2 \circ} \mathrm{C}$;

- The thermal conductivity of heat transfer fluid, which has an average value of $0.65 \mathrm{~W} / \mathrm{m}^{\circ} \mathrm{C}$;

- The heat removal coefficient, which has an average value of 0.9701 ;

- The mirror efficiency coefficient, which has an average value of 0.9843 ;

- The overall coefficient of heat loss, which has an average value of $5.96 \mathrm{~W} / \mathrm{m}^{2 \circ} \mathrm{C}$.

It is also noted that the average optical efficiency of the studied reflector was $78.55 \%$, while the maximum value of the local concentration ratio of heat flux distribution was recorded at 11:00 with a value of 116.30. This study has given a comprehensive manner on a small solar parabolic trough reflector, which can be relied upon in some areas such as water desalination and water heating. 
As a conclusion, the research team is working on designing an experimental setup for this efficient solar concentrator for use in many scientific fields such as air conditioning, desalination, swimming water heating, The Matlab user program has been proven to be very efficient and accurate in many scientific research as it was mentioned at the heart of this paper. In the coming research, this paper will support the examination of the optical side of the studied device, after which it will combine the thermal, optical and experimental side of this solar device.

\section{NOMENCLATURE}

$A_{a} \quad$ Opening area of the solar collector, $\mathrm{m}^{2}$

$A_{G, \text { ext }} \quad$ Extern surface of the glass cover, $\mathrm{m}^{2}$

$A_{r} \quad$ Copper absorber tube surface, $\mathrm{m}^{2}$

$A_{r, e x t} \quad$ Outer surface of the copper absorber tube, $\mathrm{m}^{2}$

$C L \quad$ Curve length of the reflective mirror, $\mathrm{m}$

Cp Fluid specific heat, $\mathrm{J} / \mathrm{kg}^{\circ} \mathrm{C}$

$D_{A, \text { ext }} \quad$ Outside diameter of the copper absorber tube, $\mathrm{m}$

$D_{A, i n t} \quad$ Inner diameter of the copper absorber tube, $\mathrm{m}$

$D_{G \text {,ext }} \quad$ Outer diameter of the glass cover, $\mathrm{m}$

$D_{G, \text { int }} \quad$ Inside diameter of the glass cover, $\mathrm{m}$

DNI Direct-normal irradiance, $\mathrm{W} / \mathrm{m}^{2}$

$F \quad$ Focal distance, $\mathrm{m}$

$F^{\prime} \quad$ Mirror efficiency factor

$F_{R} \quad$ Heat dissipation factor

$h_{F} \quad$ Heat transfer coefficient of fluid, $\mathrm{W} / \mathrm{m}^{2 \circ} \mathrm{C}$

$h_{r, G \text {-a }} \quad$ Radiative exchange coefficient between the glass cover and ambient air, $\mathrm{W} / \mathrm{m}^{2 \circ} \mathrm{C}$

$h_{r, r-G} \quad$ Radiative exchange coefficient between the copper receiver tube and glass cover, $\mathrm{W} / \mathrm{m}^{2 \circ} \mathrm{C}$

$h_{W} \quad$ Convective heat exchange coefficient between the glass cover and ambient air, $\mathrm{W} / \mathrm{m}^{2 \circ} \mathrm{C}$

$K\left(\theta_{i}\right) \quad$ Correction coefficient of the incidence-modified angle

$k_{\text {air }} \quad$ Thermal conductivity coefficient of air, $\mathrm{W} / \mathrm{m}^{\circ} \mathrm{C}$

$k_{F} \quad$ Thermal conductivity coefficient of $\mathrm{HTF}$ fluid, $\mathrm{W} / \mathrm{m}^{\circ} \mathrm{C}$

$\ell \quad$ Mirror length, $\mathrm{m}$

$N u_{a i r} \quad$ Air Nusselt number

$\mathrm{Nu}_{F} \quad$ Fluid Nusselt number

$O p_{\text {error }} \quad$ Overall average optical error

$Q_{\text {gain }} \quad$ Heat energy acquired by fluid, W

Qlost Lost energy, W

$Q_{m} \quad$ Fluid mass flow, $\mathrm{kg} / \mathrm{s}$

$Q_{S} \quad$ Solar energy Amount that reaches the reflective mirror and then reflected towards the receiver tube, W

Re Reynolds number

$r_{r} \quad$ Rim radius, $\mathrm{m}$

$T_{A b} \quad$ Copper absorber tube temperature, ${ }^{\circ} \mathrm{C}$

$T_{a m b} \quad$ Ambient air temperature, ${ }^{\circ} \mathrm{C}$

$T_{G} \quad$ Glass tube temperature, ${ }^{\circ} \mathrm{C}$

$T_{\text {HTF }} \quad$ Heat transfer fluid temperature at the exit of the receiver tube, ${ }^{\circ} \mathrm{C}$

$T_{i} \quad$ Cold fluid temperature when entering the tube, ${ }^{\circ} \mathrm{C}$

$T_{s} \quad$ Hot water temperature at the exit of the tube, ${ }^{\circ} \mathrm{C}$

$U_{L} \quad$ And global heat loss coefficient, $\mathrm{W} / \mathrm{m}^{2 \circ} \mathrm{C}$

$W \quad$ Opening width of the reflective mirror, $\mathrm{m}$

$W_{S} \quad$ Wind speed, $\mathrm{m} / \mathrm{s}$ 

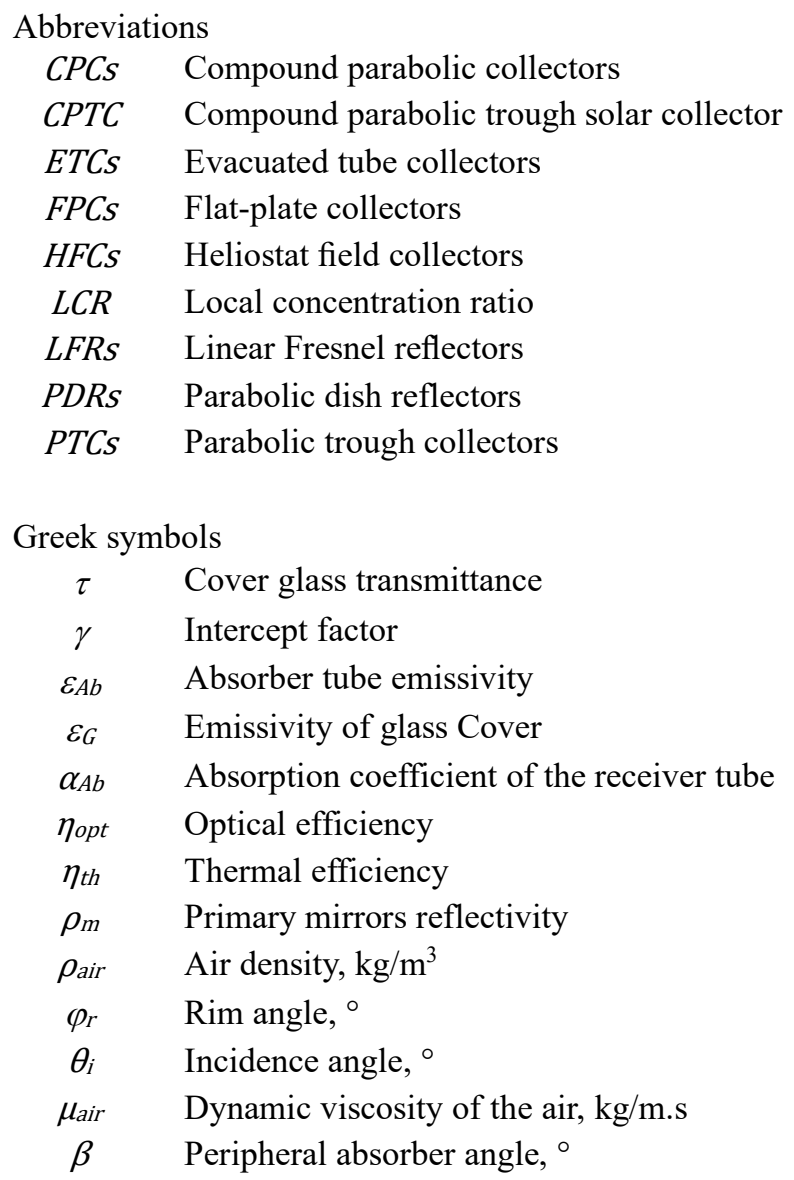

\section{REFERENCES}

[1] Said Z, Ghodbane M, Sundar LS, Tiwari AK, Sheikholeslami M, Boumeddane B. Heat transfer, entropy generation, economic and environmental analyses of linear Fresnel reflector using novel rGO-Co3O4 hybrid nanofluids. Renewable Energy. 2021;165(Part 1):420-37. https://doi.org/10.1016/j.renene.2020.11.054. doi:https://doi.org/10.1016/j.renene.2020.11.054.

[2] Ghodbane M, Benmenine D, Khechekhouche A, Boumeddane B. Brief on Solar Concentrators: Differences and Applications. Instrumentation Mesure Metrologie. 2020;19(5):371-8. https://dx.doi.org/10.18280/i2m.190507.

[3] Bellos E. Progress in the design and the applications of Linear Fresnel Reflectors - A critical review. Thermal Science and Engineering Progress. 2019;10(May 2019):112-37. https://doi.org/10.1016/j.tsep.2019.01.014.

[4] Delgado-Marín JP, García FV, García-Cascales JR. Use of a predictive control to improve the energy efficiency in indoor swimming pools using solar thermal energy. Solar Energy. 2019;179:380-90. https://doi.org/10.1016/j.solener.2019.01.004.

[5] Ghodbane M, Boumeddane B, Moummi N, Largot S, Berkane H. Study and numerical simulation of solar system for air heating. Journal of Fundamental and Applied Sciences. 2016;8(1):41- 60, http://dx.doi.org/10.4314/jfas.v8i1.3.

[6] Yıldırım C. Theoretical Investigation of a Solar Air Heater Roughened by Ribs and Grooves. Journal of Thermal Engineering. 2018;4(1):1702-12. https:/dx.doi.org/10.18186/journal-of-thermal-engineering.365713.

[7] Singh J, Singh R, Bhushan B. Thermo-Hydraulic Performance of Solar Air Heater Duct having Triangular Protrusions as Roughness Geometry. Journal of Thermal Engineering 2015;1(7):607-20. https://dx.doi.org/10.18186/jte.01332.

[8] Ghodbane M, Boumeddane B, Said N. A linear Fresnel reflector as a solar system for heating water: theoretical and experimental study. Case Studies in Thermal Engineering. 2016;8(C):176-86, http://dx.doi.org/10.1016/j.csite.2016.06.006.

[9] Ghodbane M, Said Z, Hachicha AA, Boumeddane B. Performance assessment of linear Fresnel solar reflector using MWCNTs/DW nanofluids. Renewable Energy. 2020;151:43-56. https://doi.org/10.1016/j.renene.2019.10.137. 
[10] Ghodbane M, Bellos E, Said Z, Boumeddane B, Hussein AK, Kolsi L. Evaluating energy efficiency and economic effect of heat transfer in copper tube for small solar linear Fresnel reflector. Journal of Thermal Analysis and Calorimetry. 2020:https://doi.org/10.1007/s10973-020-09384-6. doi:https://doi.org/10.1007/s10973-020-093846.

[11] Said Z, Ghodbane M, Hachicha AA, Boumeddane B. Optical performance assessment of a small experimental prototype of linear Fresnel reflector Case Studies in Thermal Engineering 2019:100541. https://doi.org/10.1016/j.csite.2019.

[12] kerme E, Kaneesamkandi Z. Performance Analysis and Design of Liquid Based Solar Heating System. Journal of Thermal Engineering. 2015;1(5):182-91. https://dx.doi.org/10.18186/jte.02359.

[13] Bellos E, Said Z, Tzivanidisa C. The use of nanofluids in solar concentrating technologies: A comprehensive review. Journal of Cleaner Production. 2018;196:84-99. https://doi.org/10.1016/j.jclepro.2018.06.048.

[14] Loni R, Asli-Ardeh EA, Ghobadian B, Ahmadi MH, Bellos E. GMDH modeling and experimental investigation of thermal performance enhancement of hemispherical cavity receiver using MWCNT/oil nanofluid. Solar Energy. 2018;171:790-803. https://doi.org/10.1016/j.solener.2018.07.003.

[15] Hussein AK. Applications of nanotechnology in renewable energies-A comprehensive overview and understanding. Renewable and Sustainable Energy Reviews. 2015;42:460-76. http://dx.doi.org/10.1016/j.rser.2014.10.027.

[16] Hussein AK. Applications of nanotechnology to improve the performance of solar collectors - Recent advances and overview. Renewable and Sustainable Energy Reviews. 2016;62:767-92. http://dx.doi.org/10.1016/j.rser.2016.04.050.

[17] Rizi AP, Ashrafzadeh A, Ramezani A. A financial comparative study of solar and regular irrigation pumps: Case studies in eastern and southern Iran. Renewable Energy.138:1096-103. https://doi.org/10.16/j.renene.2019.02.026.

[18] Powell JW, Welsh JM, Farquharson R. Investment analysis of solar energy in a hybrid diesel irrigation pumping system in New South Wales, Australia. Journal of Cleaner Production. 2019;224: 444-54. .

[19] Costa BA, Lemos JM, Guillot E. Solar furnace temperature control with active cooling. Solar Energy. 2018;159: 66-77. http://dx.doi.org/10.1016/j.solener.2017.10.017.

[20] Indora S, Kandpal TC. Financial appraisal of using Scheffler dish for steam based institutional solar cooking in India. Renewable Energy. 2019;135:1400-11. https://doi.org/10.016/j.renene.2018.09.067.

[21] Ahmed FE, Hashaikeh R, Hilal N. Solar powered desalination - Technology, energy and future outlook. Desalination. 2019; 453:54-76.

[22] Ghasemi A, Hashemian N, Noorpoor A, Heidarnejad P. Exergy Based Optimization of a Biomass and Solar Fuelled CCHP Hybrid Seawater Desalination Plant. Journal of Thermal Engineering. 2017;3(1):1034-43. https:/dx.doi.org/10.18186/thermal.290251.

[23] Stegou-Sagia A, Fragkou DV. Thin Layer Drying Modeling of Apples and Apricots in A Solar-Assisted Drying System. Journal of Thermal Engineering. 2018;4(1):1680-91. https:/dx.doi.org/10.18186/journal-of-thermalengineering.364909.

[24] Attia MEH, Driss Z, Ghodbane M, Hussein AK, Rout SK, Li D, editors. Experimental Study of the Temperature Distribution Inside an Indirect Solar Dryer Chamber. Advances in Air Conditioning and Refrigeration; 2021; Singapore: Springer Singapore.

[25] Zoukit A, El-Ferouali H, Salhi I, Doubabi S, Abdenouri N. Takagi Sugeno fuzzy modeling applied to an indirect solar dryer operated in both natural and forced convection. Renewable Energy. 2019;133:849-60. https://doi.org/10.1016/j.renene.2018.10.082.

[26] Ghodbane M, Boumeddane B, Said Z, Bellos E. A numerical simulation of a linear Fresnel solar reflector directed to produce steam for the power plant. Journal of Cleaner Production. 2019;231:494-508. https://doi.org/10.1016/j.jclepro.2019.05.201.

[27] Bouguila A, Said R. Optimization of a Small Scale Concentrated Solar Power Plant Using Rankine Cycle. Journal of Thermal Engineering. 2020;6(3):268-81. https://dx.doi.org/10.18186/thermal.711287.

[28] Taner T, Dalkilic AS. A Feasibility Study of Solar Energy - Economic Analysis from Aksaray, Turkey. Journal of Thermal Engineering. 2019;5(1):25-30. https:/dx.doi.org/10.18186/thermal.505498.

[29] Ghodbane M, Bellos E, Said Z, Boumeddane B, Khechekhouche A, Sheikholeslami M et al. Energy, Financial and Environmental investigation of a direct steam production power plant driven by linear Fresnel solar reflectors. Journal of Solar Energy Engineering. 2020.

[30] Mazzeo D. Solar and wind assisted heat pump to meet the building air conditioning and electric energy demand in the presence of an electric vehicle charging station and battery storage. Journal of Cleaner Production. 2019;213:1228-50. https://doi.org/10.016/j.jclepro.2018.12.212. 
[31] Fong KF, Lee CK, Lin Z. Investigation on effect of indoor air distribution strategy on solar air-conditioning systems. Renewable Energy. 2019;131:413-21. https://doi.org/10.1016/j.renene.2018.07.065.

[32] Ghodbane M, Boumeddane B, Hussein AK. Performance analysis of a solar-driven ejector air conditioning system under El-Oued climatic conditions, Algeria Journal of Thermal Engineering. 2021;7(1):172-89. https://dx.doi.org/10.18186/thermal.847334.

[33] Anand Y, Gupta A, Tyagi S, Anand S. Variable Capacity Absorption Cooling System Performance for Building Application. Journal of Thermal Engineering. 2018;4(5):2303-17. https:/dx.doi.org/10.18186/thermal.439041.

[34] Pulido-Iparraguirre D, Valenzuela L, Aguilera JJ, Fernández-Garcíaa A. Optimized design of a Linear Fresnel reflector for solar process heat applications. Renewable Energy. 2019;131:1089-106. https://doi.org/10.16/j.renene.2018.08.018.

[35] Baniassadi A, Momen M, Amidpour M, Pourali O. Modeling and design of solar heat integration in process industries with heat storage. Journal of Cleaner Production. 2018;170:522-34. https://doi.org/10.1016/j.jclepro.2017.09.183.

[36] Farjana SH, Huda N, Parvez-Mahmud MA, Saidur R. Solar process heat in industrial systems - A global review. Renewable and Sustainable Energy Reviews. 2018;82:2270-86. http://dx.doi.org/10.1016/j.rser.2017.08.065.

[37] Bellos E, Korres D, Tzivanidis C, Antonopoulos KA. Design, simulation and optimization of a compound parabolic collector. Sustainable Energy Technologies and Assessments. 2016;16:53-63. https://doi.org/10.1016/j.seta.2016.04.005.

[38] Shafieian A, Khiadani M, Nosrati A. Thermal performance of an evacuated tube heat pipe solar water heating system in cold season. Applied Thermal Engineering. 2019;149:644-57. https://doi.org/10.1016/j.applthermaleng.2018.12.078.

[39] Bellos E, Tzivanidis C. Performance analysis and optimization of an absorption chiller driven by nanofluid based solar flat plate collector. Journal of Cleaner Production. 2018;174:256-72. https://doi.org/10.1016/j.jclepro.2017.10.313.

[40] Kalogirou SA. Solar thermal collectors and applications. Progress in Energy and Combustion Science. 2004;30(3): 231-95. https://doi.org/10.1016/j.pecs.2004.02.001.

[41] Bellos E, Tzivanidis C, Moghimi MA. Reducing the optical end losses of a linear Fresnel reflector using novel techniques. Solar Energy. 2019;186: 247-56. https://doi.org/10.1016/j.solener.2019.05.020.

[42] Kasaeian A, Loni R, Asli-Ardeh EA, Ghobadian B, Shahverdi K. Comparison Study of Air and Thermal Oil Application in a Solar Cavity Receiver. Journal of Thermal Engineering. 2019;5(6):221-9. https://dx.doi.org/10.18186/thermal.654628.

[43] Kasaeian A, Loni R, Asli-Ardeh EA, Ghobadian B, Shahverdi K. Thermal Evaluation of Cavity Receiver using Water/PG as the Solar Working Fluid. Journal of Thermal Engineering. 2019;5(5):446-55. https://dx.doi.org/10.18186/thermal.624341.

[44] Bellos E, Tzivanidis C. Alternative designs of parabolic trough solar collectors. Progress in Energy and Combustion Science. 2019;71:81-117. https://doi.org/10.1016/j.pecs.2018.11.001.

[45] Yettou F. Receiver Temperature Maps of Parabolic Collector Used for Solar Food Cooking Application in Algeria. Journal of Thermal Engineering. 2018;4(1):1656-67. https:/dx.doi.org/10.18186/journal-of-thermalengineering.364866.

[46] Ghodbane M. Étude et optimisation des performances d'une machine de climatisation a éjecteur reliée à un concentrateur solaire Université Saad Dahleb, Blida 1, Algérie 2017.

[47] Hussein AK, Ghodbane M, Said Z, Ward RS. The Effect of the Baffle Length on the Natural Convection in an Enclosure Filled with Different Nanofluids. Journal of Thermal Analysis and Calorimetry. 2020.

[48] Said Z, Abdelkareem MA, Rezk H, Nassef AM. Fuzzy modeling and optimization for experimental thermophysical properties of water and ethylene glycol mixture for $\mathrm{Al} 2 \mathrm{O} 3$ and $\mathrm{TiO} 2$ based nanofluids. Powder Technology. 2019;353:345-58.

[49] Said Z, Abdelkareem MA, Rezk H, Nassef AM, Atwany HZ. Stability, thermophysical and electrical properties of synthesized carbon nanofiber and reduced-graphene oxide-based nanofluids and their hybrid along with fuzzy modeling approach. Powder Technology. 2020:https://doi.org/10.1016/j.powtec.2020.02.026. doi:https://doi.org/10.1016/j.powtec.2020.02.026.

[50] Said Z, Arora S, Bellos E. A review on performance and environmental effects of conventional and nanofluidbased thermal photovoltaics. Renewable and Sustainable Energy Reviews. 2018;94:302-16. https://doi.org/10.1016/j.rser.2018.06.010. doi:https://doi.org/10.1016/j.rser.2018.06.010.

[51] Said Z, Assad MEH, Hachicha AA, Bellos E, Abdelkareem MA, Alazaizeh DZ et al. Enhancing the performance of automotive radiators using nanofluids. Renewable and Sustainable Energy Reviews. 2019;112:183-94. 
[52] Said Z, El Haj Assad M, Hachicha AA, Bellos E, Abdelkareem MA, Alazaizeh DZ et al. Enhancing the performance of automotive radiators using nanofluids. Renewable and Sustainable Energy Reviews. 2019;112:183-94. https://doi.org/10.1016/j.rser.2019.05.052.

[53] Said Z, Saidur R, Rahim NA. Energy and exergy analysis of a flat plate solar collector using different sizes of aluminium oxide based nanofluid. Journal of Cleaner Production. 2016;133:518-30. https://doi.org/10.1016/j.jclepro.2016.05.178. doi:https://doi.org/10.1016/j.jclepro.2016.05.178.

[54] Said Z, Saidur R, Sabiha MA, Hepbasli A, Rahim NA. Energy and exergy efficiency of a flat plate solar collector using $\mathrm{pH}$ treated Al2O3 nanofluid. Journal of Cleaner Production. 2016;112:3915-26. https://doi.org/10.1016/j.jclepro.2015.07.115. doi:https://doi.org/10.1016/j.jclepro.2015.07.115.

[55] Said Z, Saidur R, Sabiha MA, Rahim NA, Anisur MR. Thermophysical properties of Single Wall Carbon Nanotubes and its effect on exergy efficiency of a flat plate solar collector. Solar Energy. 2015;115:757-69. https://doi.org/10.1016/j.solener.2015.02.037. doi:https://doi.org/10.1016/j.solener.2015.02.037.

[56] Mebarek-Oudina F, Makinde OD. Numerical Simulation of Oscillatory MHD Natural Convection in Cylindrical Annulus: Prandtl Number Effect. Defect and Diffusion Forum. 2018;387:417-27. http://dx.doi.org/10.4028/www.scientific.net/DDF.387.417.

[57] Raza J, Mebarek-Oudina F, Chamkha AJ. Magnetohydrodynamic flow of molybdenum disulfide nanofluid in a channel with shape effects. Multidiscipline Modeling in Materials and Structures. 2019;15(4):737-57, https://doi.org/10.1108/MMMS-07-2018-0133.

[58] Alkasassbeh M, Omar Z, Mebarek-Oudina F, Raza J, Chamkha A. Heat transfer study of convective fin with temperature-dependent internal heat generation by hybrid block method. Heat Transfer-Asian Research. 2019;48(4):1225-44. https://doi.org/10.002/htj.21428.

[59] Mebarek-Oudina F. Convective heat transfer of Titania nanofluids of different base fluids in cylindrical annulus with discrete heat source. Heat Transfer-Asian Research. 2019;48(1):135-47. https://doi.org/10.1002/htj.21375.

[60] Korres D, Bellos E, Tzivanidis C. Investigation of a nanofluid-based compound parabolic trough solar collector under laminar flow conditions. Applied Thermal Engineering. 2019;149:366-76. https://doi.org/10.1016/j.applthermaleng.2018.12.077.

[61] Ghodbane M, Boumeddane B. Engineering design and optical investigation of a concentrating collector: Case study of a parabolic trough concentrator J Fundam Appl Sci. 2018;10(2):148-71. http://dx.doi.org/10.4314/jfas.v10i2.11.

[62] Manikandan GK, Iniyan S, Goic R. Enhancing the optical and thermal efficiency of a parabolic trough collector - A review. Applied Energy. 2019;235:1524-40. https://doi.org/10.016/j.apenergy.2018.11.048.

[63] Azzouzi D, Bourorga HE, Belainine KA, Boumeddane B. Experimental study of a designed solar parabolic trough with large rim angle. Renewable Energy. 2018;125:495-500, https://doi.org/10.1016/j.renene.2018.01.041.

[64] Fernandez-Garcia A, Zarza E, Valenzuela L, Perez M. Parabolic-trough solar collectors and their applications. Renewable and Sustainable Energy Reviews. 2010;14:1695-721, https://doi.org/10.016/j.rser.2010.03.012.

[65] Donga RK, Kumar S. Thermal performance of parabolic trough collector with absorber tube misalignment and slope error. Solar Energy. 2019;184:249-59. https://doi.org/10.1016/j.solener.2019.04.007.

[66] Bellos E, Tzivanidis C, Tsimpoukis D. Optimum number of internal fins in parabolic trough collectors. Applied Thermal Engineering. 2018;137:669-77. https://doi.org/10.1016/j.applthermaleng.2018.04.037.

[67] Bellos E, Daniil I, Tzivanidis C. Multiple cylindrical inserts for parabolic trough solar collector. Applied Thermal Engineering. 2018;143:80-9. https://doi.org/10.1016/j.applthermaleng.2018.07.086.

[68] Bellos E, Tzivanidis C. Parametric analysis and optimization of an Organic Rankine Cycle with nanofluid based solar parabolic trough collectors. Renewable Energy. 2017;114(Part B):1376-93. https://doi.org/10.016/j.renene.2017.06.055s.

[69] Bellos E, Tzivanidis C, Daniil I, Antonopoulos KA. The impact of internal longitudinal fins in parabolic trough collectors operating with gases. Energy Conversion and Management. 2017;135:35-54. https://doi.org/10.1016/j.enconman.2016.12.057.

[70] Bellos E, Tzivanidis C, Tsimpoukis D. Thermal enhancement of parabolic trough collector with internally finned absorbers. Solar Energy. 2017;157:514-31. https://doi.org/10.1016/j.solener.2017.08.067.

[71] Bellos E, Tzivanidis C. Thermal analysis of parabolic trough collector operating with mono and hybrid nanofluids. Sustainable Energy Technologies and Assessments. 2018;26:105-15. https://doi.org/10.1016/j.seta.2017.10.005.

[72] Bellos E, Tzivanidis C. Parametric investigation of nanofluids utilization in parabolic trough collectors. Thermal Science and Engineering Progress. 2017;2:71-9. https://doi.org/10.1016/j.tsep.2017.05.001.

[73] Bellos E, Tzivanidis C. Investigation of a booster secondary reflector for a parabolic trough solar collector. Solar Energy. 2019;179:174-85. https://doi.org/10.1016/j.solener.2018.12.071. 
[74] Bellos E, Tzivanidis C. Investigation of a star flow insert in a parabolic trough solar collector. Applied Energy. 2018;224:86-102. https://doi.org/10.1016/j.apenergy.2018.04.099.

[75] Bellos E, Tzivanidis C, Tsimpoukis D. Enhancing the performance of parabolic trough collectors using nanofluids and turbulators. Renewable and Sustainable Energy Reviews. 2018;91:358-75. https://doi.org/10.1016/j.rser.2018.03.091.

[76] Moloodpoor M, Mortazavi A, Ozbalta N. Thermal analysis of parabolic trough collectors via a swarm intelligence optimizer. Solar Energy. 2019;181:264-75. https://doi.org/10.1016/j.solener.2019.02.008.

[77] Ghodbane M, Boumeddane B, Said N. Design and experimental study of a solar system for heating water utilizing a linear Fresnel reflector. Journal of Fundamental and Applied Sciences. 2016;8(3):804-25, http://dx.doi.org/10.4314/jfas.v8i3.8.

[78] Kalogirou SA. Performance of solar collectors. Solar energy engineering : processes and systems. Academic Press of Elsevier; 2009. p. 219-50.

[79] Duffie JA, Beckman WA. Collector tests: Efficiency, incidence angle modifier,and time constant. In: John Wiley \& Sons I, editor. Solar Engineering of Thermal Processes. 2013. p. 289-98.

[80] Ghodbane M, Boumeddane B. Optical modeling and thermal behavior of a parabolic trough solar collector in the Algerian sahara AMSE JOURNALS-AMSE IIETA, MMC_B. 2017;86(2):406-26. https://doi.org/10.18280/mmc_b.860207 